\title{
Determination of Free and Bound Amino Acids in Plant Raw Materials of Zea mays L. by the Method of High-Performance Liquid Chromatography
}

\author{
Uliana V. Karpiuk, Victoriia S. Kyslychenko', Irina S. Cholak, Oksana I. Yemelianova \\ Department of Pharmacognosy and Botany, Bogomolets National Medical University, Kiev, 'Department of Chemisry of Natural Compounds and Nutriciology, \\ National University of Pharmacy, Kharkiv, Ukraine
}

\begin{abstract}
Background: Plants have long been considered as a source of easily digestible forms of amino acids in combination with other biologically active compounds. Objectives: The aim of our research was to study the amino acid composition of the roots, leaves, and silk of Zea mays. Materials and Methods: The qualitative composition and the quantitative content of the free and the bound amino acids have been studied by the methods of paper chromatography and the high-performance liquid chromatography. Results: The content of the bound amino acids is significantly higher than the content of free amino acids in the studied plant material. The presence of 11 free amino acids and 16 bound amino acids has been found after the hydrolysis of aqueous solutions of the roots, leaves, and silk of $Z$. mays. Cysteine dominates quantitatively among the bound amino acids in all samples. The roots have the lowest amino acid content compared to other samples of raw materials. Conclusions: Results show the availability to use the $Z$. mays raw material for the production of complex remedies and functional food additives that contain amino acid complexes.
\end{abstract}

Key words: Amino acids, high-performance liquid chromatography, leaves, roots, Zea mays L. silk

\section{SUMMARY}

- Z. mays leaves, silk and roots content free and bound amino acids

- The sum of nonessential amino acids prevail.

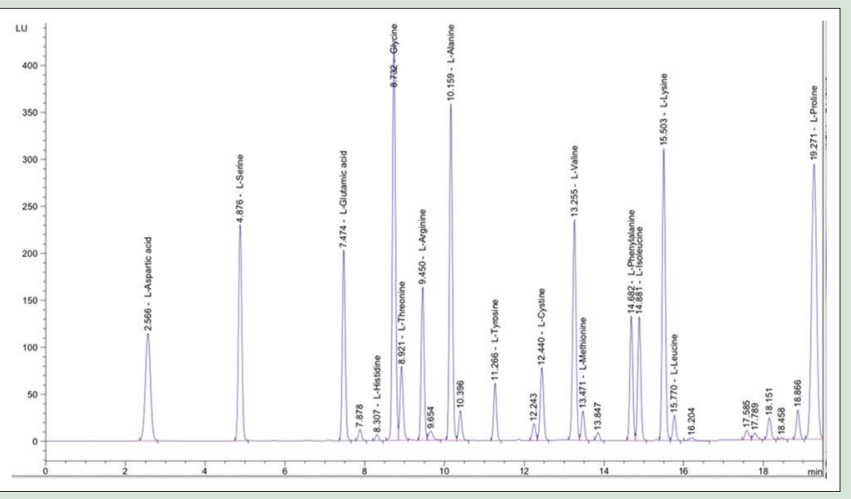

Abbreviations Used: Ala: Alanine, Ar: Arginine, Asp: Asparagine, Cy: Cysteine, Glu: Glutamic acid, Gly: Glycine, His: Histidine, Ile: Isoleucine,

Leu: Leucine, Lys: Lysine, Met: Methionine, Phe: Phenylalanine, Pro: Proline, Ser: Serine, Thr: Threonine, Tyr: Tyrosine, Val: Valine.

Correspondence:

Dr. Uliana V. Karpiuk,

Bogomolets National Medical University, 13,

T. Shevchenko Bulv., Kyiv 01601, Ukraine.

E-mail: uliana.karpiuk@gmail.com

DOI: $10.4103 / p r . p r+78 \_19$
Access this article online Website: www.phcogres.com

Quick Response Code:

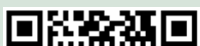

\section{INTRODUCTION}

Plant amino acids can be divided into two types: proteinogenic and non-proteinogenic amino acids. There are about twenty amino acids found in each living system. They are present in plant materials in the free condition and also as a part of other substances. The qualitative composition of amino acids varies greatly in different plants, as well as in the tissues of one plant. However, glutamic and aspartic acids and their acid amides - glutamine and asparagine (Asp) - tend to be found in plant tissues in larger amounts than other amino acids. This is due to their participation in the biosynthesis of proteins because they are a reserve source of nitrogen in plants. By contrast, histidine (His), tryptophan, cysteine (Cy), and methionine (Met) are more often present in very small amounts in plant tissues. Therefore, sometimes, they may not be identified. ${ }^{[1]}$

Amino acids are included in the biosynthesis of almost all nitrogen-containing compounds of plants, through proteins: alkaloids, amines, cyanoglycosides, porphyrins, purines, pyrimidines, and cytokinins. ${ }^{[1-3]}$

Amino acids are of great importance for normal human life because they have an important nutritional value. Amino acids are included in the biosynthesis of proteins and enzymes. Glycine (Gly), alanine (Ala), phenylalanine (Phe), Met, aspartic acid, and lysine (Lys) are usually a

required part of peptides and proteins. Threonine (Thr), tryptophan, Met, isoleucine (Ile), leucine (Leu), Phe, histidine, Lys, arginine, and valine (Val) belong to the essential amino acids that are not produced by living organisms on their own and must come from outside. ${ }^{[2,3]}$

Amino acids have a positive pharmacological effect on the human body and are used as medicines. In addition, free amino acids are involved in the process of binding, transport, and elimination of biologically active forms of nitrogen and heavy metals from the human body, and they have an immunomodulatory effect. ${ }^{[4,5]}$ Featuring a wide range of pharmacological actions, amino acids can give microelements and other compounds a pharmacological safe and easily digestible form, while potentiating their effects. ${ }^{[5]}$

This is an open access journal, and articles are distributed under the terms of the Creative Commons Attribution-NonCommercial-ShareAlike 4.0 License, which allows others to remix, tweak, and build upon the work non-commercially, as long as appropriate credit is given and the new creations are licensed under the identical terms.

For reprints contact: reprints@medknow.com

Cite this article as: Karpiuk UV, Kyslychenko VS, Cholak IS, Yemelianova OI. Determination of free and bound amino acids in plant raw materials of zea mays $L$. by the method of high-performance liquid chromatography. Phcog Res 2020;12:143-8. 
The chemical composition and pharmacological properties of many medicinal plants are well studied. Many studies associate the pharmacological action of these plants with the presence of such biologically active substances as steroids, phenolic compounds, terpenes, and alkaloids. However, plants have long been considered as a source of easily digestible forms of amino acids in combination with other biologically active compounds as well.

In order to systematically study the composition of the biologically active substances of corn, it was advisable to conduct a comparative study of the qualitative composition and quantitative content of free and bound amino acids of corn leaves, silk, and roots (variety Svetlana).

\section{MATERIALS AND METHODS}

The raw materials of Zea mays - leaves, silk, and roots - were harvested in the phase of milky-wax ripeness of the grain. Corn material is grown on research areas of the State Institution "Institute of Plant Industry named for V. Ya. Yuriev UAAN” (Kharkov, Ukraine). Raw materials were collected in July-August 2017-2018 in the Kharkiv region (Ukraine), crushed, and air-dried in shade.

The confirmation of the presence of amino acids in the raw materials of $Z$. mays was performed by qualitative reactions to identify amino acids in the studied raw materials. The free amino acids were determined by the method of paper chromatography (three-fold chromatography) in water extracts from the roots, silk, and leaves of $Z$. mays. The chromatograph paper - Filtrak FN 7 - was used: mobile phase: N-butanol-acetic acid-water (4:1:5).

The chromatogram with the applied substances was placed in a chamber with the indicated solvent system. After the solvent passed one-third of the length of a sheet of chromatographic paper, the chromatogram was removed and dried. The second time, the chromatogram was placed in the same system, with the difference that the solvent passed half of the length of the sheet. The third time, the solvent passed to the front line. A ninhydrin solution $(0.1 \%)$ and heating to $96^{\circ} \mathrm{C}$ were used to detect the amino acid spots. ${ }^{[1]}$

Quantitative determination of free and bound proteinogenic amino acids in plant materials was carried out by high-performance liquid chromatography (HPLC). The method is based on the extraction of free amino acids from plant materials, acid hydrolysis, and subsequent analysis of hydrolysates by HPLC.

Chromatographic separation was performed on a liquid chromatograph Agilent 1200 (Agilent Technologies, USA): Column Zorbax AAA $(150 \mathrm{~mm} \times 4.6 \mathrm{~mm} \times 3 \mu \mathrm{m})$. The precolumn derivatization was performed in an automatically programmed mode, followed by fluorescent detection: mobile phase $\mathrm{A}$ - a solution of sodium phosphate dibasic $(40 \mathrm{mM}) \mathrm{pH} 7.8$ and mobile phase B - acetonitrile: methanol: water (45:45:10). The separation mode was gradient at constant flow rate of $1.5 \mathrm{ml} / \mathrm{min}$. Column was thermostated at $40^{\circ} \mathrm{C}$. The number of experiments during the analysis was five. ${ }^{[6-8]}$

Sample preparation and analysis of plant materials: (a) for free amino acids: a portion of powdered raw material was placed in a vial $(2 \mathrm{ml})$, and an aqueous solution of $1 \mathrm{~N}$ hydrochloric acid was added and kept in an ultrasonic bath at $50^{\circ} \mathrm{C}$ for $3 \mathrm{~h}$ and (b) for the sum of amino acids: a sample was placed in a vial $(2 \mathrm{ml})$, and an aqueous solution of $6 \mathrm{~N}$ hydrochloric acid was added and placed in a thermostat at $110^{\circ} \mathrm{C}$. The hydrolysis was carried out for $24 \mathrm{~h}$.

Then, $0.5 \mathrm{ml}$ of the centrifuged extract/hydrolyzate was evaporated on a rotary vacuum evaporator, washing three times with distilled water to remove hydrochloric acid, resuspended in $0.5 \mathrm{ml}$ of distilled water, and filtered through $0.2 \mu \mathrm{m}$ regenerated cellulose filters.

The preparation of fluorescent derivatives was carried out in an automatic programmed mode before introducing the sample into the chromatographic column. Identification of amino acids was done by comparing the retention times of water extracts with the retention times of a mixture of amino acid standards (Agilent 5061-3334).

The content of bound amino acids was determined by subtracting the content of free amino acids from the total content [Figures 1 and 2].

\section{RESULTS AND DISCUSSION}

The paper chromatography method identified the free amino acids in leaves, roots, and silk of Z. mays as serine (Ser), Gly, Lys, Thr, glutamic acid (Glu), Val, Asp, Arg, Ala, and proline (Pro). After processing the

Table 1: Quantitative content of identified amino acids of Zea mays L. silk

\begin{tabular}{|c|c|c|c|c|c|c|}
\hline \multirow[t]{2}{*}{ Number } & \multirow[t]{2}{*}{ Amino acid } & \multicolumn{2}{|c|}{ Free } & \multicolumn{2}{|c|}{ Sum } & \multirow{2}{*}{$\begin{array}{l}\text { Bound } \\
(\mu \mathrm{g} / \mathrm{mg})\end{array}$} \\
\hline & & Retention time & $\mu \mathrm{g} / \mathrm{mg}$ & Retention time & $\mu \mathrm{g} / \mathrm{mg}$ & \\
\hline 1 & Asp & 2.57 & 0.12 & 2.56 & 4.08 & 3.96 \\
\hline 2 & Ser & 4.88 & 0.11 & 4.87 & 4.40 & 4.28 \\
\hline 3 & Glu & 7.48 & 0.23 & 7.47 & 3.70 & 3.46 \\
\hline 4 & $\mathrm{His}^{*}$ & - & - & 8.30 & 1.07 & 1.07 \\
\hline 5 & Gly & 8.75 & Traces & 8.73 & 2.99 & 2.97 \\
\hline 6 & Thr ${ }^{*}$ & 8.93 & 0.17 & 8.92 & 2.97 & 2.79 \\
\hline 7 & $\mathrm{Ar}^{*}$ & 9.45 & Traces & 9.45 & 2.70 & 2.68 \\
\hline 8 & Ala & 10.17 & 0.24 & 10.15 & 3.37 & 3.13 \\
\hline 9 & Tyr & - & - & 11.26 & 1.35 & 1.35 \\
\hline 10 & Сy & - & - & 12.44 & 13.91 & 13.91 \\
\hline 11 & $\mathrm{Val}^{*}$ & 13.27 & Traces & 13.25 & 1.92 & 1.83 \\
\hline 12 & $\operatorname{Met}^{\star}$ & - & - & 13.47 & 0.46 & 0.46 \\
\hline 13 & $\mathrm{Phe}^{*}$ & 14.70 & 0.18 & 14.68 & 2.33 & 2.15 \\
\hline 14 & $\mathrm{Ile}^{*}$ & - & - & 14.88 & 1.88 & 1.88 \\
\hline 15 & Lys $^{*}$ & 15.53 & Traces & 15.50 & 5.28 & 5.24 \\
\hline 16 & $\mathrm{Leu}^{*}$ & - & - & - & - & - \\
\hline 17 & Pro & 19.29 & Traces & 19.27 & 3.22 & 3.17 \\
\hline \multicolumn{2}{|c|}{ The sum of essential amino acids } & - & 0.49 & - & 18.59 & 18.10 \\
\hline \multicolumn{2}{|c|}{ The sum of nonessential amino acid } & - & 0.77 & - & 37.0 & 36.23 \\
\hline \multicolumn{2}{|c|}{ The sum of amino acids } & - & 1.26 & - & 55.59 & 54.33 \\
\hline
\end{tabular}

${ }^{\star}$ Essential amino acid. Asp: Asparagine; Ser: Serine; Glu: Glutamic acid; His: Histidine; Gly: Glycine; Thr: Threonine; Ar: Arginine; Ala: Alanine; Tyr: Tyrosine; Cy: Cysteine; Val: Valine; Met: Methionine; Phe: Phenylalanine; Ile: Isoleucine; Lys: Lysine; Leu: Leucine; Pro: Proline 


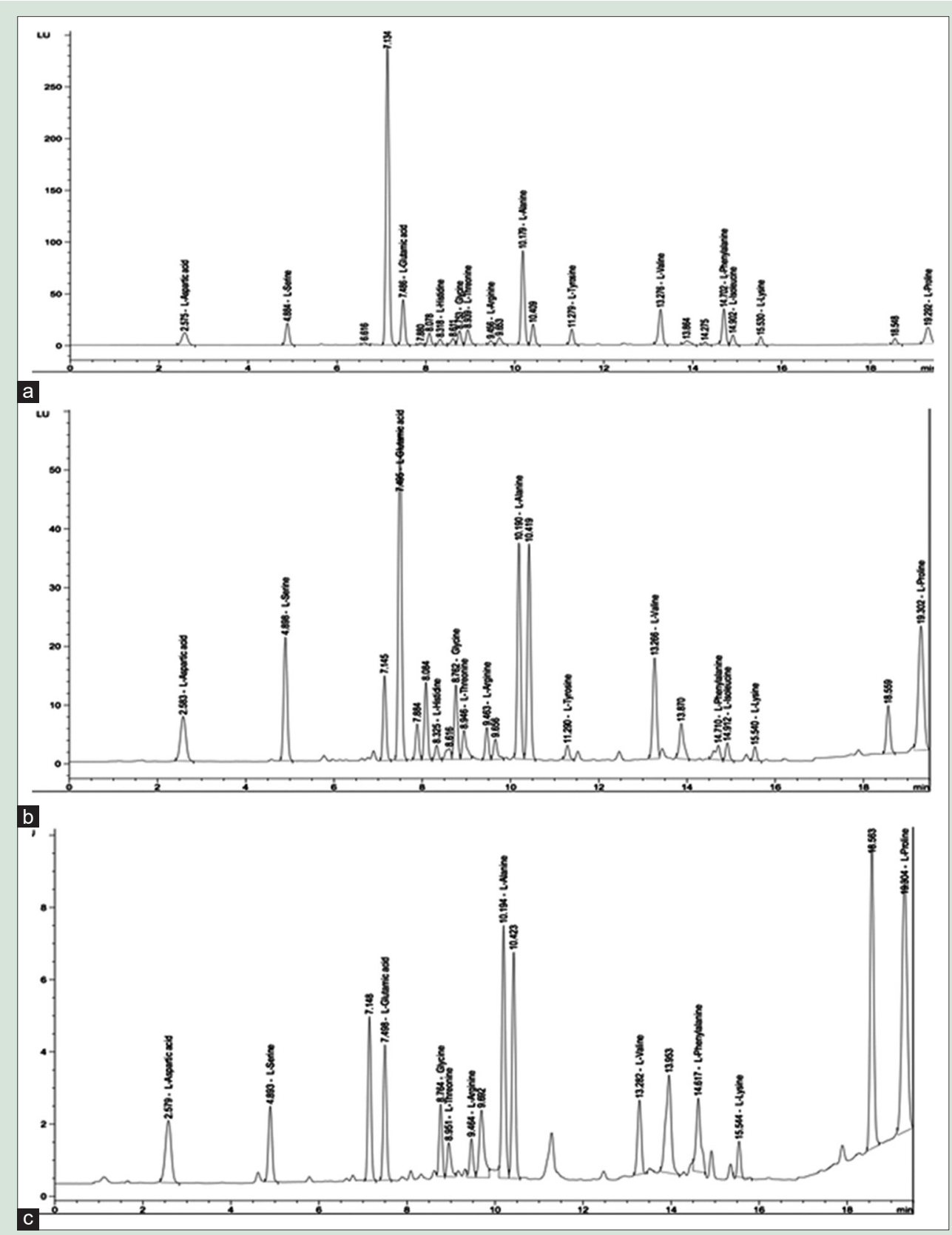

Figure 1: Chromatograms of free amino acids of Zea mays raw materials: (a) silk; (b) leaves; (c) roots

chromatogram, Ser, Val, Glu, Lys, Arg, Thr, and Ala gave purple spots; Gly - red-violet; Asp - blue-violet; and Pro - yellow. ${ }^{[1]}$

HPLC identified 11 free amino acids in Z. mays silk [Table 1], Z. mays leaves [Table 2], and Z. mays roots [Table 3]: Asp, Ser, Glu, Gly, Thr, Arg, Ala, Val, Phe, Lys, and Pro. The quantitative content of free amino acids was not significant in all types of raw materials of $Z$. mays. The sum of amino acids in the leaves exceeds the sum of amino acids in the roots and silk. The smallest amount of free amino acids was found in the roots of $Z$. mays.

Glu $(0.23 \pm 0.01 \mu \mathrm{g} / \mathrm{mg})$ and Ala $(0.24 \pm 0.01 \mu \mathrm{g} / \mathrm{mg})$ are indicated in the greatest amount in $Z$. mays silk; Glu $(1.97 \pm 0.07 \mu \mathrm{g} / \mathrm{mg})$, Ala $(1.28 \pm 0.05 \mu \mathrm{g} / \mathrm{mg})$, and Pro $(1.19 \pm 0.04 \mu \mathrm{g} / \mathrm{mg})$ are indicated in the greatest amount in $Z$. mays leaves. These free essential amino acids have been found in corn leaves, silk, and roots in small amounts: Thr, Arg, Val, Phe, and Lys.
HPLC identified 16 bound amino acids in Z. mays silk [Table 1], $Z$. mays leaves [Table 2], and $Z$. mays roots [Table 3]. There was a trend of a significant increase in the amount of amino acids after hydrolysis. The sum of amino acids after hydrolysis was $54.33 \mu \mathrm{g} / \mathrm{mg}$ in silk, $34.79 \mu \mathrm{g} / \mathrm{mg}$ in leaves, and $16.89 \mu \mathrm{g} / \mathrm{mg}$ in roots.

Cys was found in corn silk in the greatest amount: $13.91 \mu \mathrm{g} / \mathrm{mg}$. The amount of other amino acids is significantly less: Lys $-5.24 \mu \mathrm{g} / \mathrm{mg}$, Ser $-4.28 \mu \mathrm{g} / \mathrm{mg}$, Asp $-3.96 \mu \mathrm{g} / \mathrm{mg}$, Glu $-3.46 \mu \mathrm{g} / \mathrm{mg}$, Pro $-3.17 \mu \mathrm{g} / \mathrm{mg}$, Ala $-3.13 \mu \mathrm{g} / \mathrm{mg}$, Gly $-2.97 \mu \mathrm{g} / \mathrm{mg}$, Thr $-2.79 \mu \mathrm{g} / \mathrm{mg}$, Arg $-2.68 \mu \mathrm{g} / \mathrm{mg}$, Phe $-2.15 \mu \mathrm{g} / \mathrm{mg}$, Ile $-1.88 \mu \mathrm{g} / \mathrm{mg}$, Val $-1.83 \mu \mathrm{g} / \mathrm{mg}$, tyrosine (Tyr) $-1.35 \mu \mathrm{g} / \mathrm{mg}$, His $-1.07 \mu \mathrm{g} / \mathrm{mg}$, and Met $-0.46 \mu \mathrm{g} / \mathrm{mg}$. His, Tyr, Cys, Met, and Ile were identified only after hydrolysis. Leu was absent.

The contents of Cys $(9.12 \mu \mathrm{g} / \mathrm{mg})$, Asp (5.69 $\mu \mathrm{g} / \mathrm{mg})$, Lys $(4.25 \mu \mathrm{g} / \mathrm{mg})$, Ser $(3.74 \mu \mathrm{g} / \mathrm{mg})$, and Phe $(2.25 \mu \mathrm{g} / \mathrm{mg})$ were the greatest in $Z$. mays 

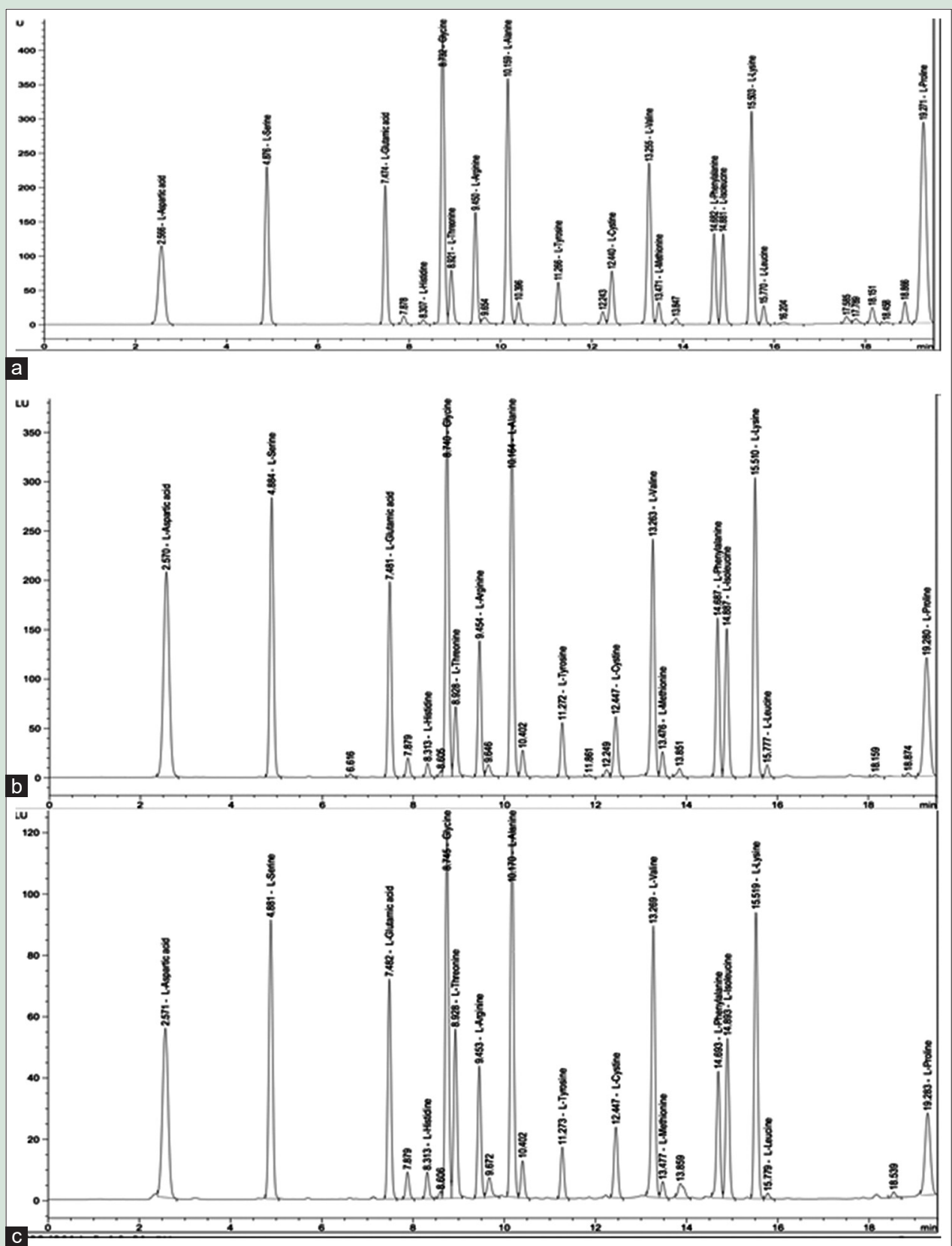

Figure 2: Chromatograms of free and bound amino acids of Zea mays raw materials: (a) silk; (b) leaves; (c) roots

leaves. Gly, Ile, Leu, Lys, and Pro were present in amounts $<2 \mu \mathrm{g} / \mathrm{mg}$. Pro was present in the least amount $-0.13 \mu \mathrm{g} / \mathrm{mg}$. Leu was absent. His, Tyr, Cys, Met, and Ile were identified only after hydrolysis.

The contents of bound Cys (3.54 $\mu \mathrm{g} / \mathrm{mg})$, Thr (1.73 $\mu \mathrm{g} / \mathrm{mg})$, Asp (1.67 $\mu \mathrm{g} / \mathrm{mg})$, Ser (1.50 $\mu \mathrm{g} / \mathrm{mg})$, Lys $(1.37 \mu \mathrm{g} / \mathrm{mg})$, His $(1.24 \mu \mathrm{g} / \mathrm{mg})$, and Glu $(1.13 \mu \mathrm{g} / \mathrm{mg})$ have been found in the corn roots after hydrolysis. Other amino acids, such as Gly, Arg, Ala, Tyr, Val, Met, Phe, Ile, and Pro, were present in amounts $<1 \mu \mathrm{g} / \mathrm{mg}$. Leu was absent. Some amino acids were found only in bound form: His, Tyr, Cys, Met, and Ile.

Bound amino acids from $Z$. mays silk, leaves, and roots included seven essential amino acids (His, Thr, Arg, Val, Met, Phe, Ile, and Lys). The content of Met was the least in all samples.

One of the indicators of biological value of mixtures of amino acids is the content of essential amino acids in them. It should be $45 \%-50 \%$ of the sum of all amino acids in order to show the high biological value of the plant raw material. ${ }^{[9]}$ The analysis of the content of essential amino acids of corn silk, leaves, and roots did not show high biological value $(<40 \%)$.

The highest sum of amino acids was in silk $(55.59 \mu \mathrm{g} / \mathrm{mg})$. The sum of corn leaves was $49.77 \mu \mathrm{g} / \mathrm{mg}$. The roots showed the smallest sum $(17.33 \mu \mathrm{g} / \mathrm{mg})$.

It is noted in the agricultural literature that corn silage and green fodder has low protein level..$^{[10,11]}$ The results obtained for the composition and content of amino acids confirm this statement.

Nevertheless, it is necessary to note the high content of Cys in all studied samples of Z. mays. Cys is an amino acid that is known as a strong antioxidant. Cys also binds to toxic metals, plays an important role in the formation of skin tissues, and promotes rapid regeneration after surgery 
ULIANA KARPIUK, et al.: Determination of Free and Bound Amino Acids in Plant Raw Materials of Zea mays L. by the Method of High-Performance Liquid Chromatography

Table 2: Quantitative content of identified amino acids of Zea mays L. leaves

\begin{tabular}{|c|c|c|c|c|c|c|}
\hline \multirow[t]{2}{*}{ Number } & \multirow[t]{2}{*}{ Amino acid } & \multicolumn{2}{|c|}{ Free } & \multicolumn{2}{|c|}{ Sum } & \multirow{2}{*}{$\begin{array}{l}\text { Bound } \\
\text { ( } \mathrm{gg} / \mathrm{mg}\end{array}$} \\
\hline & & Retention time & $\mu \mathrm{g} / \mathrm{mg}$ & Retention time & $\mu \mathrm{g} / \mathrm{mg}$ & \\
\hline 1 & Asp & 2.58 & 0.45 & 2.57 & 6.13 & 5.69 \\
\hline 2 & Ser & 4.89 & 0.81 & 4.88 & 4.56 & 3.74 \\
\hline 3 & Glu & 7.49 & 1.97 & 7.48 & 3.03 & 1.06 \\
\hline 4 & $\mathrm{His}^{*}$ & - & - & 8.31 & 1.90 & 1.90 \\
\hline 5 & Gly & 8.76 & 0.44 & 8.74 & 2.08 & 1.64 \\
\hline 6 & Thr ${ }^{*}$ & 8.94 & 0.22 & 8.92 & 2.20 & 1.98 \\
\hline 7 & $\mathrm{Ar}^{*}$ & 9.46 & 0.19 & 9.45 & 1.90 & 1.72 \\
\hline 8 & Ala & 10.19 & 1.28 & 10.16 & 2.83 & 1.54 \\
\hline 9 & Tyr & - & - & 11.27 & 1.02 & 1.02 \\
\hline 10 & $\mathrm{Cy}$ & - & - & 12.44 & 9.12 & 9.12 \\
\hline 11 & $\mathrm{Val}^{*}$ & 13.26 & 0.72 & 13.26 & 1.60 & 0.88 \\
\hline 12 & Met $^{*}$ & - & - & 13.47 & 0.31 & 0.31 \\
\hline 13 & $\mathrm{Phe}^{*}$ & 14.71 & Traces & 14.68 & 2.39 & 2.25 \\
\hline 14 & $\mathrm{Ile}^{*}$ & - & - & 14.88 & 1.81 & 1.81 \\
\hline 15 & Lys* & 15.54 & Traces & - & 4.33 & 4.25 \\
\hline 16 & Leu $^{*}$ & - & - & - & - & - \\
\hline 17 & Pro & 19.30 & 1.19 & 19.28 & 1.06 & 0.13 \\
\hline \multicolumn{2}{|c|}{ The sum of essential amino acids } & - & 1.35 & - & 12.3 & 10.95 \\
\hline \multicolumn{2}{|c|}{ The sum of nonessential amino acid } & - & 6.14 & - & 30.08 & 23.94 \\
\hline \multicolumn{2}{|c|}{ The sum of amino acids } & - & 7.49 & - & 49.77 & 34.79 \\
\hline
\end{tabular}

*Essential amino acid. Asp: Asparagine; Ser: Serine; Glu: Glutamic acid; His: Histidine; Gly: Glycine; Thr: Threonine; Ar: Arginine; Ala: Alanine; Tyr: Tyrosine; Cy: Cysteine; Val: Valine; Met: Methionine; Phe: Phenylalanine; Ile: Isoleucine; Lys: Lysine; Leu: Leucine; Pro: Proline

Table 3: Quantitative content of identified amino acids of Zea mays L. roots

\begin{tabular}{|c|c|c|c|c|c|c|}
\hline \multirow[t]{2}{*}{ Number $\Pi / \Pi$} & \multirow[t]{2}{*}{ Amino acid } & \multicolumn{2}{|c|}{ Free } & \multicolumn{2}{|c|}{ Sum } & \multirow{2}{*}{$\begin{array}{l}\text { Bound } \\
(\mu \mathrm{g} / \mathrm{mg})\end{array}$} \\
\hline & & Retention time & $\mu \mathrm{g} / \mathrm{mg}$ & Retention time & $\mu \mathrm{g} / \mathrm{mg}$ & \\
\hline 1 & Asp & 2.57 & Traces & 2.57 & 1.69 & 1.67 \\
\hline 2 & Ser & 4.89 & Traces & 4.88 & 1.51 & 1.50 \\
\hline 3 & Glu & 7.49 & Traces & 7.48 & 1.15 & 1.13 \\
\hline 4 & $\mathrm{His}^{*}$ & - & - & 8.31 & 1.24 & 1.24 \\
\hline 5 & Gly & 8.76 & Traces & 8.74 & 0.70 & 0.70 \\
\hline 6 & Thr ${ }^{*}$ & 8.95 & Traces & 8.92 & 1.74 & 1.73 \\
\hline 7 & $\mathrm{Ar}^{*}$ & 9.46 & Traces & 9.45 & 0.61 & 0.61 \\
\hline 8 & Ala & 10.19 & Traces & 10.17 & 0.97 & 0.96 \\
\hline 9 & Tyr & - & - & 11.27 & 0.32 & 0.32 \\
\hline 10 & $\mathrm{Cy}$ & & - & 12.44 & 3.54 & 3.54 \\
\hline 11 & $\mathrm{Val}^{*}$ & 13.28 & Traces & 13.26 & 0.61 & 0.60 \\
\hline 12 & Met* $^{*}$ & - & - & 13.47 & Traces & Traces \\
\hline 13 & Phe $^{*}$ & 14.61 & Traces & 14.69 & 0.66 & 0.65 \\
\hline 14 & $\mathrm{Ile}^{*}$ & - & - & 14.89 & 0.65 & 0.65 \\
\hline 15 & Lys $^{*}$ & 15.54 & Traces & 15.51 & 1.37 & 1.37 \\
\hline 16 & Leu $^{*}$ & - & - & - & - & - \\
\hline 17 & Pro & 19.30 & Traces & 19.28 & 0.24 & 0.22 \\
\hline \multicolumn{2}{|c|}{ The sum of essential amino acids } & - & - & - & 6.92 & 6.88 \\
\hline \multicolumn{2}{|c|}{ The sum of nonessential amino acid } & - & - & - & 10.45 & 10.06 \\
\hline \multicolumn{2}{|c|}{ The sum of amino acids } & - & 0.123 & - & 17.33 & 16.89 \\
\hline
\end{tabular}

${ }^{\star}$ Essential amino acid. Asp: Asparagine; Ser: Serine; Glu: Glutamic acid; His: Histidine; Gly: Glycine; Thr: Threonine; Ar: Arginine; Ala: Alanine; Tyr: Tyrosine; Cy: Cysteine; Val: Valine; Met: Methionine; Phe: Phenylalanine; Ile: Isoleucine; Lys: Lysine; Leu: Leucine; Pro: Proline

and burns; it also accelerates the process of fat burning and muscle formation..$^{[5,12,13]}$

\section{CONCLUSIONS}

The analysis of the qualitative composition and quantitative content of free and bound amino acids of $Z$. mays leaves, silk, and root (variety Svetlana) was carried out using paper chromatography and HPLC.

At least 11 compounds were found among the free amino acids and at least 16 amino acids among the bound ones.

The content of bound amino acids significantly exceeds the content of free amino acids in all types of plant materials in this study.
Corn leaves, silk, and roots contain Cys in a bound form in the largest quantity.

The roots have the lowest content of amino acids, compared to leaves and silk.

The composition and content of amino acids of $Z$. mays aspartic acid leaves, silk, and roots show low biological value; however, they can be used to produce complex drugs and functional food supplements which include amino acid complexes.

\section{Financial support and sponsorship}

Nil. 
ULIANA KARPIUK, et al.: Determination of Free and Bound Amino Acids in Plant Raw Materials of Zea mays L. by the Method of High-Performance Liquid Chromatography

\section{Conflicts of interest}

There are no conflicts of interest.

\section{REFERENCES}

1. Harborne JB. Phytochemical Methods. $2^{\text {nd }}$ ed. London, New York: Chapman\&Hall; 2013.

2. Cseke LJ, Kirakosyan A, Kaufman PB, Warber S, Duke JA, Brielmann HL. Natural Products from Plants. $2^{\text {nd }}$ ed. Boca Raton, Boston, London, New York, Washington, D.C.: CRC Press; 2006.

3. Séquin M. The Chemistry of Plants: Perfumes, Pigments and Poisons. Cambridge: Royal Society of Chemistry; 2012.

4. Salyga N, Salyga U. The influence of L-glutamic acid on the activity of enzymes on glutathione metabolism and the intensity of peroxid processes in rats. Visnyk Lviv University. Biol Ser 2013;62:61-7.

5. Shamsizade LA, Novruzov EN. The composition and content of free amino acids in the fruits of some medicinal fruit-bearing plants. News Biol Sci $2011 ; 66: 112-9$.

6. Jámbor A, Molnár-Perl I. Amino acid analysis by high-performance liquid chromatography after derivatization with 9-fluorenylmethyloxycarbonyl chloride Literature overview and further study. J Chromatogr A 2009;1216:3064-77.

7. Jámbor A, Molnár-Perl I. Quantitation of amino acids in plasma by high performance liquid chromatography: Simultaneous deproteinization and derivatization with 9-fluorenylmethyloxycarbonyl chloride. J Chromatogr A 2009;1216:6218-23.

8. Karpyuk UV, Kislichenko VS, Gureva IG. HPLC Determination of Free and Bound Amino Acids in Bryonia alba. Chem Nat Compd 2015;51:399-400.

9. Farmanova NT, Urnamova FD, Komilov KH. The study of amino acid composition of the diuretic herb collection "Stymphlos". Pharm J 2005;1:13-5.

10. Gnoievyi VI, Golovko VO, Trishyn OK, Gnoievyi IV. The Feeding of Highly Productive Cows. Kharkiv: Prapor; 2009.

11. Kumar D, Jhariya AN. Nutritional, medicinal and economical importance of corn: A min review. Res J Pharm Sci 2013;2:1-2.

12. Zapadniuk VN, Kuprash LP, Znyka MU. Amino Acids in Medicine. Kiev: Zdorovie; 1982.

13. Brazhko OA. L-cysteine synthon for the production of biologically active substances. Bull Zaporizhzhya National University: Collection of scientific articles. Biol Sci 2009;4:65-80 